\title{
John Prebble
}
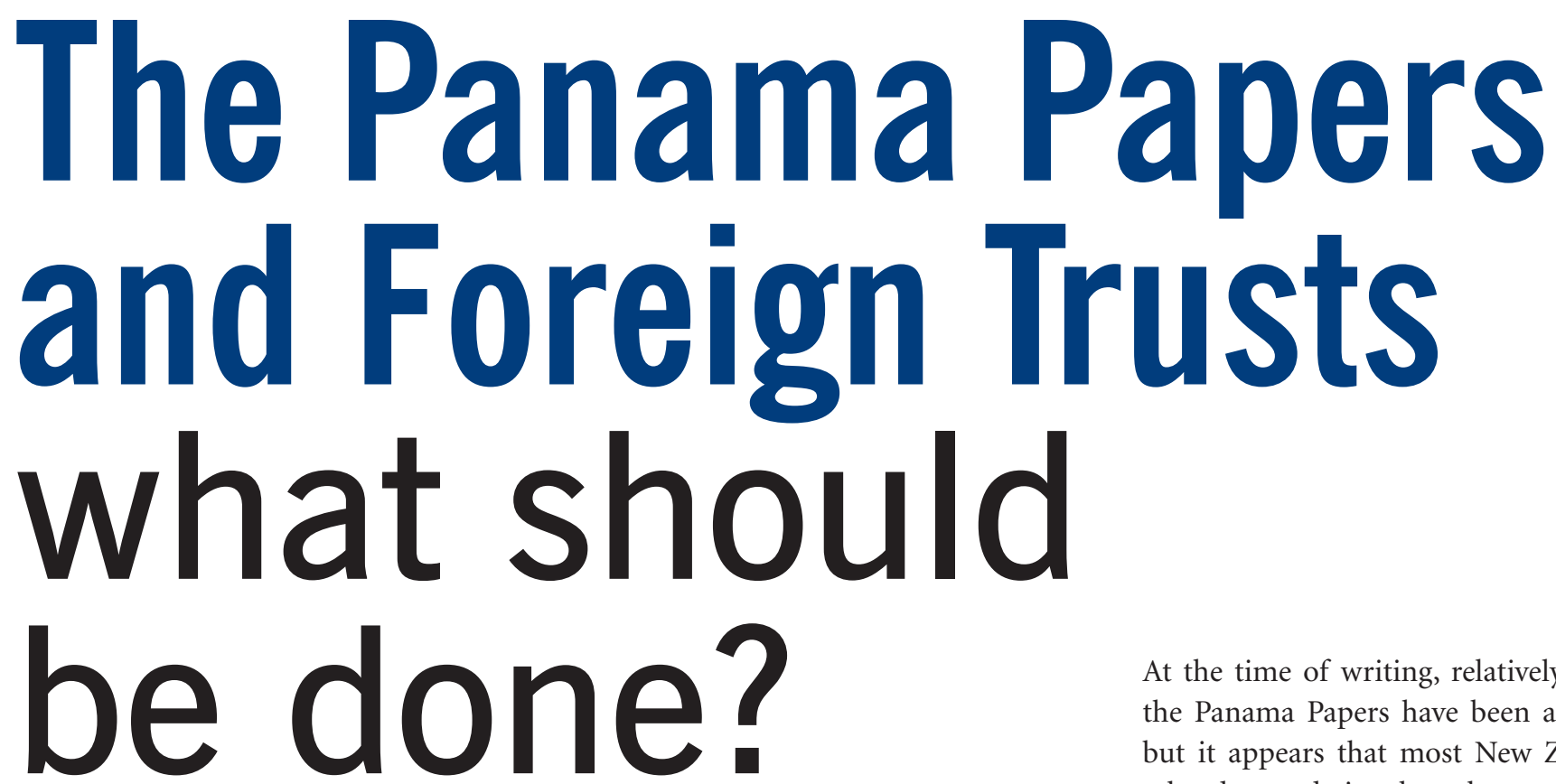

The Panama Papers and foreign trusts

On 3 April 2016 the International Consortium of

Investigative Journalists (ICIJ) and the German newspaper

Süddeutsche Zeitung announced that for the past year they

had been analysing a cache of 11.5 million records, now

known as the Panama Papers, taken from the Panamanian

law firm Mossack Fonseca. The cache included documents

relating to trusts and companies in several tax havens. The

ICIJ gave details of a number of users or beneficial owners

of these structures. Sixty thousand of the records related to

New Zealand.

John Prebble QC is Professor of Law at Victoria University of Wellington; Gastprofessor, Institut für Österreichisches und Internationales Steuerrecht, Wirtschaftsuniversität Wien; and Adjunct Professor of Law, School of Law, University of Notre Dame, Sydney.

At the time of writing, relatively few of the Panama Papers have been analysed, but it appears that most New Zealandrelated records involve what are known as 'foreign trusts'. A number of New Zealand companies specialise in setting up and operating foreign trusts for nonresidents. Solicitors and accountants often provide the same service. The industry is thought to earn over $\$ 25$ million a year (Pullar-Strecker, 2016), though the present author suspects that the sum is rather more.

'Foreign trust' is a concept of the Income Tax Act 2007. Broadly speaking, and over-simplifying, a foreign trust has one or more New Zealand-resident trustees but no New Zealand-source income and no settlor or settlors who are or were resident in New Zealand. Beneficiary residence does not matter, since residents of New Zealand, and thus beneficiaries of any trust who are resident in New Zealand, must pay tax on all income wherever it comes from. Nevertheless, in practice few foreign 
trusts have beneficiaries that reside in New Zealand. That is, counter-intuitively, a 'foreign trust' is a trust with at least one New Zealand-resident trustee where the settlor and income are foreign. Generally speaking, as will be explained, New Zealand does not tax the income of foreign trusts.

The concern with foreign trusts is that in addition to legitimate uses, New Zealand foreign trusts can be employed to avoid or evade income tax of other countries, to hold stolen wealth, or as repositories for profits from illegal activities.

On 11 April 2016 the government appointed John Shewan to investigate foreign trusts, to report and to make recommendations as to what, if anything, should be done about them. His report (Shewan, 2016) was published on 27 June. In summary, Shewan recommends that New Zealand should maintain a register of foreign trusts, including their deeds, that discloses settlor(s), protector (if any), trustees and beneficiaries (with provisions for beneficiaries of discretionary trusts) (p.3). The objective is to provide information that Inland Revenue and certain other authorities can search if need be to respond to inquiries from foreign tax administrations and other foreign officials, such as people charged with investigating money laundering. The ministers of finance and revenue responded on 13 July 2016, adopting the recommendations of the report with few modifications (English and Woodhouse, 2016). This article addresses the issue of foreign trusts in general, together with some aspects of Shewan's report. The article focuses on income tax, although the report itself is more wide-ranging. Some knowledge of the history and nature of trusts and of international taxation may help readers to understand the issues.

\section{History and nature of trusts}

A trust is better thought of as a remedy or a relationship than as an entity. The trust developed within the common law (that is, judge-made law) in mediaeval England. For instance, when a baron accompanied the king on a crusade he might convey the title to his castle to his neighbour. Having legal title to the castle, the neighbour could repel adverse claims, both in court and by force if necessary. But what happened if the neighbour refused to re-convey the castle on the crusader's return? Since the crusader had voluntarily granted legal title to the neighbour, the common law offered no remedy.

Such injustice offended the conscience of the king, and, by later delegation, of the king's lord chancellor, and then of the courts of equity. The remedy was to throw the neighbour into prison until he gave common law title to the castle back to the crusader. That is, the system of law that came to be known as 'equity' did not itself effect justice, but compelled defendants to act justly within the common law. Equity operates in the same way today, to prevent people from abusing their rights under the common law. eventually to distribute it to beneficiaries. A primary example is the deceased estate. The law, and common sense, forbad testators from leaving property directly to infants, so testators appointed trustees to hold their property after death, to pay or to retain income from the property, and to distribute the capital in due course.

\section{Flexibility of trusts}

At this point, a particular quality of the common law becomes relevant. Essentially, the common law permits people to do anything that is not forbidden. That is why, with few exceptions, parties can form binding contracts to do almost anything. Trusts reflect the same quality of flexibility. Subject to very few restrictions, settlors can specify precisely how capital and income of a trust must be distributed (fixed trusts), or they

\section{The concern with foreign trusts is that in addition to legitimate uses, New Zealand foreign trusts can be employed to avoid or evade income tax of other countries, to hold stolen wealth, or as repositories for profits from illegal activities.}

The crusader's remedy came to be institutionalised as the trust. In conveying title to the neighbour, the crusader was a settlor who settled property on trust. In accepting the property subject to obligations to hold it for the benefit of the crusader and to return it to him the neighbour became a trustee. The beneficiaries of the trust were the crusader, or his heirs if he did not return. The example illustrates that, in contrast to, say, a company, the trust is fundamentally a remedy rather than an entity. It is also a creation of the common law, not of statute.

Property owners began to use the trusts paradigm to answer other needs. For instance, when they foresaw that they would not be able to look after their property personally they 'settled' their property on trustees to look after it and can leave decisions wholly or partly to the discretion of the trustee, or even of someone else (discretionary trusts). Trusts can substitute for the settlor, for instance, after death, as explained, or they can protect assets: from corrupt governments intent on looting their citizens; from tax gatherers; or from creditors and spouses. Trusts can sometimes protect, or at least hide, assets stolen from the true owner.

The basis for this flexibility is that trust law recognises that property may be subject to two forms of ownership at the same time. Legal ownership vests in the trustee, whose name appears on titles and registers if ownership must be recorded. Beneficial ownership resides in the beneficiaries, but that ownership may in practice be both unknowable and tentative: unknowable to anyone who does not know that the title holder to property 
is only a trustee; and provisional because beneficiaries' interests may depend on the exercise of a discretion that has not occurred.

Trusts can be so flexible that the same person may be at the same time all of settlor, trustee and beneficiary, although where a trust has only one person in all these roles the three roles are likely to merge, leaving no trust: only one person holding the property as beneficial owner. Instead, careful drafting can ensure that merger does not occur.

Broadly speaking, national borders do not trouble the common law. The law will, for example, enforce a trust settled in one country, administered in a second and holding property in a third, with trustees resident in a fourth

\section{Fixed and discretionary trusts}

In the paradigm of a trust the interests of beneficiaries are fixed. For instance, a trustee of an estate may hold the property of the estate to pay the income to the testator's widow during her life, and, at her death, to transfer the property to the testator's daughter. Or a testator may leave her property to trustees to sell the property and to divide the proceeds equally between her three children.

Discretionary trusts are different and take the concept of flexibility to another level. The settlor or testator may authorise the trustee to divide property between beneficiaries according to the discretion of the trustee or of another nominated person. Often, a trust will empower the trustee to omit one or

\section{People can create trusts orally, by informal action, or even by accident, if they inadvertently put themselves under fiduciary obligations to others.}

or fifth, and beneficiaries scattered in a sixth or seventh. A trustee of one trust may hold some or all of the property for the trustee of a second trust, the first often a 'custodian trustee', with no duties other than to obey the commands of the second. Paradigm trustees are individuals, known to law as 'natural persons', but, in the absence of statutory prohibition, companies and other incorporations may be trustees.

There is no trans-national law of trusts. A common law court applies the 'proper law' of the trust, being the law of the jurisdiction that is most closely connected with the trust in question, which may not be the law of the jurisdiction where the court sits. A trust deed may authorise the settlor to override the 'closest connection' test and, within wide limits, expressly choose the proper law to be applied. The deed may authorise the trustees to move the trust's administrative centre to another jurisdiction, usually appointing new trustees and replacing the proper law at the same time. more beneficiaries altogether. A trust deed may name and precisely identify beneficiaries, or simply define them, for instance by reference to a common grandfather. That is, trustees take decisions about dividing trust property that settlors would take themselves if they retained the property.

The rule in Saunders $v$ Vautier $^{1}$ provides that if all beneficiaries are of full age and absolutely entitled (that is, broadly, there is no other possible beneficiary), the beneficiaries may combine to require the trustee to transfer the property to themselves. A settlor can prevent this result by, for instance, adding a charity as a beneficiary. There may never be any intention for property to go to the charity, but its presence as a beneficiary means that the family members or others who are the substantive target of the settlor's benevolence cannot compel the trustee to terminate the trust. It is probably for this or similar technical reasons that a number of well-known charities appeared as beneficiaries of
New Zealand trusts that were identified in Mossack Fonseca's documents. If so, it is unlikely that there was any intention of passing property to the charities.

\section{Creation and drafting of trusts}

People can create trusts orally, by informal action, or even by accident, if they inadvertently put themselves under fiduciary obligations to others. ('Fiduciary' obligations arise where one party owes special duties to put the interests of the other ahead of his or her own. For instance, although the law in general allows contracting parties to exact from each other whatever profit they honestly can, an agent must not profit at the expense of her principal. Likewise, unless there is provision in the document that creates the trust, trustees must not profit from the trust property.) Nevertheless, most trusts are created formally, by recording their terms in a deed, which, in the present context, means essentially a formal document where signatures are witnessed.

Trust deeds are complex, but lawyers who practise in the area have welldeveloped precedents, so the drafting process is undemanding for the most part. Many provisions of deeds exist to replace common or statute law that would otherwise apply by default. Other provisions are calculated to ensure that the trusts in question do indeed have the tax effects that their authors intend. Mistakes are rare, especially in deeds that are drafted to create trusts that are to be employed in tax planning.

The courts tend to take deeds at face value. For instance, it is common for someone to settle a trust that is to be used by an unrelated family. Later, the substantive settlor may transfer property to the trust. The objective is to circumvent legislation that imposes tax obligations that are defined in terms of settlors of trusts. As far as New Zealand income tax is concerned, section HC 27 of the Income Tax Act 2007 frustrates that stratagem by treating anyone who transfers wealth to a trust as a settlor.

\section{Problems of the regulation of trusts}

Before considering the problems that trusts pose for international tax policy, it 
is helpful to list a number of the challenges that trusts pose to any regulatory authority:

- Unlike companies, which are created by the state (mostly under the Companies Act 1993), trusts are constructs of the common law. Just as for contracts or wills, or for private correspondence for that matter, there is no automatic way for the state to find out about trusts or to compose a register.

- Beneficial ownership is separated from legal ownership and possession, which means that it may be hard to discover the beneficial owners of property held by trustees.

- Moreover, where a law provides for registration of ownership, such as in the Land Transfer Act 1952, not only is it not customary to require registration of beneficial ownership, but it may be forbidden. ${ }^{2}$

- Trust deeds may be so drafted that the anticipated beneficiaries are identified by reference but not named, and may not be identified for many years.

- Conversely, the named beneficiary may be a charity or other not-forprofit organisation that the settlor and trustees never intend to benefit. As mentioned, this may explain why New Zealand trusts among the Panama Papers name a number of charities.

- A trust may empower the settlor, or someone else, to add beneficiaries at a later date. That is, not only are these additional beneficiaries not named in the deed; they are not even described by reference except in rather general terms.

\section{The international tax system}

Like most countries, New Zealand employs 'source' and 'residence' to determine whether income is taxable, taxing:

- all income that has its source in this country, whether derived by residents or by non-residents; and

- all income derived by residents, whether having a New Zealand source or a foreign source.
There are two important consequences. First, some income risks double taxation. For example, interest that a New Zealand resident earns in the United States is potentially taxed in both countries. The same applies to, for instance, fees, salaries, dividends, royalties and so on. Like other countries, New Zealand mitigates this burden in a number of ways. The Income Tax Act exempts certain foreign-source income from New Zealand taxation. In respect of some other income, the act grants New Zealand residents credit for foreign taxes imposed at source, subtracting the credit from New Zealand tax imposed on the same income. In addition to these unilateral measures, New Zealand that is resident in New Zealand. We will call this structure, where foreigners cause foreign-source income that they derive to be paid to a New Zealand bank, Model 1. As explained, New Zealand has no reason to tax the income of Model 1 when the bank receives it.

\section{New Zealand trust taxation}

Unlike companies, trusts are not legal persons. That is, trusts' existence comprises only their settlors, trustees, beneficiaries and trust property, and the interrelationships between them. In contrast, companies have an existence independent of their shareholders and directors, albeit a fictional existence created by the law. For trusts, it follows

\section{Using New Zealand-resident trustees to look after the income should not, and does not, make any difference to the income's fiscal status as far as New Zealand is concerned.}

has entered some 40 bilateral treaties that operate in the same way, but that are usually more generous towards the taxpayer than is the statute. These treaties are known variously as double tax treaties, agreements or conventions.

The second consequence is that where income does not have a New Zealand source and is not derived by a New Zealand resident, New Zealand makes no claim to tax. This is not surprising: why would New Zealand tax, for instance, a French resident on salary that he earns in Switzerland? But the principle goes further. Suppose that the Frenchman trusts neither French banks nor Swiss banks and asks his employer to pay the salary into an account at the Wellington branch of the Bank of New Zealand. Again, not surprisingly, New Zealand taxes neither the employee nor the bank on the salary, though New Zealand does impose tax on interest that the bank may pay or on fees that it charges, both the interest and the fees having a New Zealand source and the fees being earned by a company that the law taxes not the trust, but the trustee or the beneficiary. If trustees distribute income to beneficiaries in the year when the trustees derive it the beneficiaries are taxed, broadly speaking as if they derived the income directly rather than via the trust. ${ }^{3}$ Following the rules explained under the previous heading, tax bites if the beneficiaries are resident in New Zealand or if the income has a New Zealand source. If the income has a foreign source and the trustee pays it to a foreign-resident beneficiary there is no tax. Generally, the same applies for both fixed and discretionary trusts. We will call this structure Model 2.

In policy terms, Model 2 reflects Model 1. In Model 1 the source of the income is Swiss (foreign) and the owner of the income is French (also foreign). Using a New Zealand bank to look after the income should not, and does not, make any difference to the fiscal status of the income as far as New Zealand is concerned. In Model 2 the income is again foreign, as is the beneficial 
owner of the income, the beneficiary. Using New Zealand-resident trustees to look after the income should not, and does not, make any difference to the income's fiscal status as far as New Zealand is concerned. True, there is a legal difference between the bank and the trustee. Legally the bank is the debtor of the French account holder, whereas the trustees, as trustees, are the legal owners of the income as it passes through their hands or as they add it to the funds of the trust. But, economically, the bank and the trustee perform similar functions of looking after someone else's income. There is no reason of principle for the tax consequences to differ. whether the trustee is resident in New Zealand or abroad. But if a foreignresident trustee does not pay, then the settlor must pay, treated as agent for the trustee. ${ }^{5}$ The policy logic is that if the settlor had retained the incomeproducing property, and had derived and accumulated the income, New Zealand would tax the settlor. It should make no difference that the settlor has transferred the property to a trustee.

If neither the settlor nor the trustee is resident in New Zealand, and if the income has a foreign source, there is no policy reason (or practical ability) for $\mathrm{New}$ Zealand to tax income that the trustee retains. New Zealand simply has no

\section{... there is not truly a 'regime' at all: merely a category of income that is not taxed because it falls outside the reach of the New Zealand tax system}

So much for income that trustees pass on to beneficiaries. Income accumulated by trustees presents different problems for tax policy makers. Since trustees must not personally enjoy their trust income, one might suppose that they should not pay tax on it. But that result would allow trustees to defer tax for as long as they chose. The solution is to tax retained trust income to trustees, treating them as taxpayers who are additional to their personal taxpayer status. That is, trustees are taxpayers in respect of their personal income at the same time as being as many taxpayers as there are trusts of which they are trustees. If the source of the income is in New Zealand there are no issues: the income is simply taxable on the basis of the source rule discussed above. But what questions arise if the income comes from abroad? The answer depends on the residence of the settlor.

\section{New Zealand foreign trusts}

If the settlor is resident in New Zealand, the statute taxes the trustee. ${ }^{4}$ This is so connection with the income or relevant parties that would justify exacting tax.

The questions that are the subject of this article arise where income is foreign and settlors reside abroad, but they choose trustees resident in New Zealand. This structure is known as a 'foreign trust'. An example of a foreign trust might arise where, say, Mossack Fonseca has a client resident in Malta who wishes to settle income-producing property on trust, perhaps shares in a company registered in Luxembourg. Mossack Fonseca might commission a New Zealand law firm or trust company to establish a trust with a New Zealand-resident trustee for the benefit of the Maltese client and his family, all resident in Malta. How does New Zealand income tax treat dividends that the New Zealand trustee derives from the Luxembourg company?

If the trustee distributes the dividends to the beneficiaries, Model 2 applies. That is, foreign-source income goes to foreignresident beneficiaries and there is no reason for New Zealand to tax. The same logic applies if the trustee retains the income, which structure may be called Model 3. No one resident in New Zealand has any interest in the income. From an economic perspective the trustee is a mere custodian. ${ }^{6}$ For this reason of fiscal policy, New Zealand does not tax trustees in a Model 3 or 'foreign trust' structure. Although it is not obvious at first sight, there is no more basic policy reason to tax the trustee in Model 3 than there is to tax the bank in Model 1 or the trustee in Model 2.

A problem arises in that although there is no obvious policy reason to tax earnings retained under a Model 3 structure, countries may do so. New Zealand charged trustees tax on retained foreign-source income until the late 1980s. Other countries still do. The reason is formalistic and legal rather than economic. Lawmakers are persuaded that since trustees are the legal owners of income that arises from trust property, that is sufficient reason to tax them, even if the residence of the trustee is the only connection between the income and the taxing jurisdiction. New Zealand rejected this reasoning in the 1980 s in favour of driving tax policy by considerations of economic substance rather than of legal form. Economic substance leads to Model 3, which reflects the paradigm of Model 1: that is, no tax on foreign-source income derived by non-residents.

\section{The foreign trust 'regime' and its 'exemption'} The Shewan Report calls the tax law that applies to foreign trusts, which has just been described, the foreign trust 'regime'. This is common usage, and is for convenience used in this article, but the usage can mislead. The reason is that there is not truly a 'regime' at all: merely a category of income that is not taxed because it falls outside the reach of the New Zealand tax system. 'Regime' suggests an intended framework, perhaps calculated to confer tax benefits. That is not so in respect of foreign trusts, where 'regime' is no more than a shorthand reference to the relevant law.

For similar reasons, it can be misleading to think of foreign trusts as beneficiaries of a tax 'exemption' (eg Shewan, 2016, p.16). This is true in 
formal terms, but, as explained above, it is no more consistent with fiscal policy and logic to tax the income of a typical foreign trust than it would be to tax the salary of a foreigner who chooses to have the salary paid into a New Zealand bank.

\section{Disclosure}

Following robust economic policy in creating a model for trust taxation reveals problems that arise from the nature of trusts. Where foreigners desire to hide foreign property or income, transferring the funds to a New Zealand-resident trustee is an attractive option. For reasons that have been explained, New Zealand has no interest in levying tax on foreigners' foreign-source income and does not do so, even if the foreigners choose a New Zealand bank or trust to look after that income.

From a New Zealand perspective, foreign countries are welcome to tax income of their residents that comes to rest in a New Zealand trust. Alternatively, the foreign country could tax its own resident settlors who have contrived this result, as New Zealand would in corresponding cases of New Zealand settlors. But this is a matter of theory. In practice, if no one reports the income or the existence of the trust, then foreign countries will find it difficult or impossible to levy tax.

New Zealand could mitigate foreign countries' enforcement problems by advising revenue authorities of New Zealand residents who are trustees of foreign trusts, or even by discovering and forwarding information about their trustee income. Until 2006 this was impossible because there was no requirement for New Zealand residents to advise New Zealand authorities that they were trustees of trusts settled by foreigners to derive foreign-source income. In 2006 Parliament added section 59B to the Tax Administration Act 1994, which requires trustees in this position to advise Inland Revenue of the existence and name of the trust and to keep records in case they are asked for information. In addition, trustees must advise the commissioner if a settlor is Australian. The only result was that 'There is now virtually no participation in [New Zealand] foreign trusts from Australia' (Shewan, 2016, p.15). Other countries rarely ask Inland Revenue about New Zealand foreign trusts because they have no way of knowing that trusts relevant to their inquiries exist. If they suspect that their residents have interests in New Zealand trusts they cannot advance their knowledge without knowing the name of the trust, which is most unlikely to offer any clues as to the identity or residence of interested parties.

Two reasons suggest that New Zealand should be more forthcoming in providing information to foreign tax authorities. The first is that the present decade is seeing a major change in countries' policies towards helping each other to collect tax in general and in
Reputation: is New Zealand a tax haven?

'Tax haven' is not a term of art. Use of the expression can shed more heat than light. Nevertheless, the New Zealand foreign trust regime raises the question whether the country should be so described. The OECD suggests that four qualities define a tax haven (Shewan, 2016, p.44):

(a) no or only nominal taxes;

(b) lack of effective exchange of information;

(c) lack of transparency; and

(d) no substantial activities; to which the author would add:

(e) foreign taxpayers' ability to reduce their home country tax in return for a toll.

\section{Historically, countries did not help one another to collect tax, but globalisation, international concern about tax avoidance and increasing international cooperation in general have brought about major changes in this policy.}

exchanging information in particular. Historically, countries did not help one another to collect tax, but globalisation, international concern about tax avoidance and increasing international cooperation in general have brought about major changes in this policy. Countries now add extensive mutual assistance and information exchange articles to bilateral tax treaties; there are numerous bilateral tax information exchange agreements; and in 2012 New Zealand signed the joint OECD/Council of Europe Multilateral Convention on Mutual Administrative Assistance in Tax Matters. Cumulatively, these measures impose significant duties on New Zealand to answer requests from treaty partners for taxpayer information. New Zealand law must be amended to give the government power to respond. The second reason for New Zealand to be more forthcoming in responding to requests from foreign governments for information about foreign trusts relates to reputation.
It is true that as a country New Zealand does not fit this description, but it is equally true that the foreign trust regime does. Points (a) and (b) are obvious. Point (c) follows from the very nature of trusts: unless there are specific rules, trusts involve private transactions, without the knowledge of any authorities. And point (d) applies almost by definition to New Zealand foreign trusts, where the only onshore activity involves trust administration. Typically, all of settlors, beneficiaries, investments and income are foreign. Point (e) is clear: foreign residents can hide income in New Zealand for the cost (or toll) of establishing and maintaining a trust structure. A difference is that in New Zealand private enterprise charges the toll, rather than the government, which was, for example, the practice of the Cook Islands at the time of the 'wine box' scandal.

The Shewan Report concludes that New Zealand is not a tax haven, although 
foreign trusts might be categorised as a 'preferential tax regime' (p.45). While correct as far as it goes, this conclusion may miss the target. The expression 'preferential tax regime' usually refers to a regime that is carved out of an otherwise unexceptionable tax system to offer preferential treatment to an activity or group. For instance, until the mid-1980s New Zealand accommodated farmers with all sorts of tax preferences. In contrast, the foreign trust regime is part of the basic structure of the New Zealand system, which does not tax foreign-

\section{... structures that can hide income from taxation can equally well hide stolen funds, facilitate money laundering, enable the transfer of funds to terrorists, and provide a secure haven for the proceeds of drug dealing and other illegal trades.}

source income derived by foreigners. As explained above, it is misleading to call the trusts rules a 'regime' at all, because the 'regime' is a gap. The gap is not unintended, but exists because of fiscal policy. The regime has more in common with, say, Vanuatu, which has never had an income tax. That is, the absence of income tax is fundamental to Vanuatu's fiscal structure. For this reason, Vanuatu is an attractive base for passive investment, just as New Zealand is an attractive place for foreigners to establish trusts. If Vanuatu is a tax haven, and most would agree that it is, then New Zealand is a tax haven in respect of its trust regime.

Despite this categorisation, New Zealand's tax regime is the subject of very little disapproval in foreign official quarters. Reasons appear to include that specialists understand that far from being calculated to help people to dodge tax, the regime is founded in robust fiscal principle, supported by New Zealand's well-deserved reputation as a good international citizen. Another reason is that despite being available since 1988, the New Zealand regime remains relatively little understood and relatively little used, a factor that may explain why Mossack Fonseca seems to have begun to employ New Zealand trusts in earnest only in 2013 (Reuters, 2016). It may well be that until then Mossack Fonseca had not been fully aware of the potential of New Zealand foreign trusts.

On the other hand, as Shewan points out, there is a great deal of concern within New Zealand. He said: laundering, enable the transfer of funds to terrorists, and provide a secure haven for the proceeds of drug dealing and other illegal trades. These considerations led Shewan to recommend that New Zealand institute a register for foreign trusts, and that a copy of the trust deed and the following information should be supplied on registration:

the name, email address, foreign residential address, country of tax residence and Tax Identification Number of -

- the settlor or settlors

- the protector, if there is any

- non-resident trustees

- any other natural person who has effective control of the trust (including control through a chain of control or ownership)

- beneficiaries of fixed trusts, including the underlying beneficiary where a named beneficiary is a nominee.

- For discretionary trusts, each class of beneficiary [must] be described in sufficient detail to enable identity to be established at the time of a distribution or when vested rights are exercised (the naming of discretionary beneficiaries being impractical). [In addition, foreign trusts should] be required to file an annual return with IRD that includes -

- any changes to the information provided at registration

- the trust's annual financial statements

- the amount of any distributions paid or credited and the names, foreign address, Tax Identification Number and country of tax residence of the recipient beneficiaries. (pp.52-3)

Relevant rules relating to money laundering and the reporting of suspicious transactions should be strengthened and information sharing rules reviewed and reformed where necessary. The register would be searchable by regulatory authorities, but not open to the public.

The government's response was by way of a media release dated 13 July 2016, 
accepting Shewan's recommendations with few variations (English and Woodhouse, 2016). Inland Revenue is to administer the register, at least initially. The Department of Internal Affairs and the police will be authorised to search it. The media release does not say so explicitly, but presumably Inland Revenue will also be authorised to search, as well as to administer. Otherwise, Inland Revenue would not be able to respond effectively to exchange of information requests.

\section{A public register?}

Meantime, the Wellington Dominion Post leader of 30 June had argued that the register of foreign trusts should be public, saying:

[Shewan] has too much regard for the privacy of wealthy foreigners. Those who want to use New Zealand's law for complex and remote purposes of their own, even to 'manage family wealth', whatever that might mean, should accept transparency as the price for the privilege. (Dominion Post, 2016)

The Dominion Post's argument misses several points. First, once the register of trusts has been established it is probable that New Zealand's foreign trust industry will wither. After 2006 Australian residents, faced with much less stringent registration requirements in respect of their New Zealand trusts, almost totally abandoned the New Zealand regime. There is some reason to expect that the same will happen in respect of the rest of the world now that full registration is to be extended to them, though, to be fair to the Dominion Post, Shewan takes a different view. He says, on the basis of submissions from trust and company service providers, that many offshore parties who use New Zealand as a safe haven to hold their family wealth report their income correctly to their home jurisdictions (Shewan, 2016, p.18). It would have been informative to know why these clients use New Zealand trusts. A possibility is that they do not trust their home professional advisers to maintain confidentiality, though they do trust their countries' tax authorities in this respect. (The question of communicating details of wealth to criminals is addressed below.)

Secondly, there is the basic practice of confidentiality in respect of tax matters. We accept this value for $\mathrm{New}$ Zealand residents; why not in respect of foreigners who trust us? It is not a question of accommodating foreigners who have criminal or similar activity to hide. If foreigners are foolish enough to try to use a New Zealand trust as a vehicle of concealment, checks by Inland Revenue, the police or the Department of Internal Affairs, sometimes initiated by corresponding agencies abroad, will establish their targets, both as to persons and as to amounts to demand. Such victims are in a difficult position. Many would be happy to pay the taxes that they owe to their own countries' revenue services, but if the revenue department itself is corrupt, simply paying taxes can lead to having your children kidnapped. Some New Zealand service providers have established and run trusts for people in this position, no doubt thinking it the lesser of two evils to save their clients from criminals at the cost of suspecting that the clients will be safe only if they do not declare their taxable income.

Neither the Shewan Report nor

\section{Many would be happy to pay the taxes that they owe to their own countries' revenue services, but if the revenue department itself is corrupt, simply paying taxes can lead to having your children kidnapped.}

discover them. If there are foreigners who would like New Zealand trustees to look after their money, being foreigners who have nothing to hide from their own or from New Zealand authorities, but who might not want their neighbours, or, for that matter, criminals, to be able to look them up, why should New Zealand satisfy the neighbours' or the criminals' curiosity?

\section{Settlors as victims of crime}

For foreigners, using New Zealand trusts as a shield against criminals is no trivial matter. The present author has not personally established foreign trusts for victims of crime, but he has met victims interested in employing New Zealand trusts to protect themselves in the future.

Currently, a major category of client of the New Zealand trust industry comprises people living in lawless countries where some officials and some staff of banks and other institutions with relevant information are willing to pass the information on to kidnappers and other criminals, who use the information to the responses of the government nor the Dominion Post address this issue. Admittedly, it is hard to see how New Zealand could observe its obligations of information sharing and enforcement of laws against tax evasion, money laundering, terrorism and so on while at the same time affording protection to foreigners who legitimately fear the criminal activity of gangsters or expropriation of their property by corrupt governments. The problem is that measures that can protect people from criminals are the same measures that one might use to hide undeclared income or the proceeds of crime. Some activity within the New Zealand foreign trust industry has hitherto served the first purpose, but Shewan suspects, with good cause, that it has also served the second (p.40). Some structures probably serve both purposes at once. The focus of the report, and of proposed government action, is on the second. Should there be action in respect of the first? 
To unpack the question just asked: should New Zealand provide a safe haven for the fortunes of foreigners who live in countries where they are at risk from criminal activity? New Zealand might offer a service similar to that of Switzerland, which helped European Jews to hide wealth from Nazi Germany, though without, one would hope, the occasional sequel of retaining possession of property where owners die (e.g. Volcker, 1999). A related question is: in modern conditions, is it practical to offer a safe haven in this manner? when the matter primarily in question is wealth rather than life and limb, the implied criticism is more likely to be contentious.

Secondly, New Zealand will extradite both without and with a treaty. If there is no treaty, New Zealand retains greater powers to decline to extradite. By extradition treaties, countries mutually agree to limit their power to decline extradition requests. The corollary is that countries are careful about both the parties and the terms of their extradition treaties. But this care need relate only to

\section{The Shewan Report is commendable, though one might have preferred it to include a section on the position of foreigners who are threatened by disclosure of their wealth to criminals.}

\section{Possible safe haven rules}

We can test practicality by imagining a possible system. New Zealand could establish the foreign trusts register that the government proposes, but could include a rule that for a list of named countries New Zealand would not respond to requests for information without giving the subject of the request an opportunity to submit that the request should be declined. The procedure could correspond to procedures for extradition requests: New Zealand retains power to decline to extradite prisoners on the basis that, for instance, New Zealand cannot trust assurances of fair procedures by the requesting nation. The author suspects that this approach, attractive as it may seem, is impractical, for several reasons.

First, declining to extradite on the basis of apprehension as to fair treatment is diplomatically awkward, but New Zealand will take this step in order to ensure that prisoners have fair trials and, if found guilty, will not be subject to punishments that New Zealand would not accept. In those circumstances we accept the diplomatic risk of offending requesting countries. But, somehow, the one issue: extradition. In contrast, double tax treaties relate primarily to the relief of double taxation, with exchange of information typically being the subject of only one treaty article. Negotiation of double tax treaties is not easy at any time; adding terms that in effect express a lack of confidence in the tax administration of the partner state would necessarily make the process more difficult.

Thirdly, there the treaty in question is a multilateral convention for mutual assistance, New Zealand will not necessarily know which countries will decide to adhere to the treaty. Further, such treaties typically provide that a requested state may decide to give notice of requests to its own nationals or residents, but not to the nationals or residents of the requesting country. Certain articles of the OECD Convention on Mutual Administrative Assistance in Tax Matters, to which New Zealand is a party, are relevant:

Article 4(3): Any Party may, by a declaration addressed to one of the Depositaries, indicate that, according to its internal legislation, its authorities may inform its resident or national before transmitting information concerning him ...

Article 7(1)(a) [Spontaneous exchange of information]: A Party shall, without prior request, forward to another Party information of which it has knowledge in the following circumstances: (a) the first-mentioned Party has grounds for supposing that there may be a loss of tax in the other Party.

Article 21(1) [Protection of persons and limits to the obligation to provide assistance]: Nothing in this Convention shall affect the rights and safeguards secured to persons by the laws or administrative practice of the requested State.

Article 21(1) might permit New Zealand to decline to transmit information without hearing from a party that is the subject of a request, even where that party is a resident of the requesting state, but article 7(1)(a) would directly attack a structure whereby a resident of a country where tax information is insecure arranged for wealth to be hidden in a New Zealand trust to prevent information going to tax authorities who might pass the information on to criminals. Such a structure ex hypothesi involves a loss of tax to the state in question.

It is not impossible that New Zealand could contrive a way to circumvent these rules for the benefit of threatened taxpayers in other countries, but even if that were so, it is not likely that the foreigners in question, knowing that their identities and tax affairs were searchable, would risk confiding their wealth to New Zealand trustees.

Cases of victims kidnapped in countries where information is not secure are tragic. It behoves the government at least to consider: (a) whether New Zealand should attempt to help these people; and, if so, (b) whether such help is practical in the context of the network of obligations that is now part of the international tax system. The author suspects that the answer to (b) will be no, which probably means that question (a) is moot. But government does not 
seem to have addressed the matter and the present brief article is not a sufficient basis for a decision of such gravity.

\section{Discretionary trusts}

This article has not addressed the question of discretionary trusts in any detail. They are mentioned briefly for completeness. The report recommends in respect of discretionary trusts that the filing requirement should be:

each class of beneficiary [must] be described in sufficient detail to enable identity to be established at the time of a distribution or when vested rights are exercised (the naming of discretionary beneficiaries being impractical). (Shewan, 2016, p.53)

It would seem theoretically possible to draft a trust that appears to relate to residents of country A, whereas the true intended beneficiaries live in country B. This fact may not be registrable for many years, until there is a distribution or until rights vest. Meantime, therefore, country B has no reason to inquire about the trust. Possibly other disclosure requirements will be wide enough to flush this kind of arrangement out, but the rules will need careful drafting. It may be possible to draft an anti-avoidance rule to require disclosure of facts behind trusts that contrive to escape the rules for registration by the kind of stratagem described here.

\section{Conclusion}

For reasons of space, this article is selective in addressing issues that arise in respect of foreign trusts in general and of the Shewan Report in particular. The Shewan Report is commendable, though one might have preferred it to include a section on the position of foreigners who are threatened by disclosure of their wealth to criminals. The report was produced with remarkable speed. It shows that issues of reputation risk for New Zealand may appear more serious inside the country than looking at New Zealand from abroad (Shewan part 9), but reputational risk could increase. More decisive, however, are New Zealand's increasing obligations to collaborate with other countries in suppressing tax evasion, money laundering, terrorism and other international crime. The rules that apply to foreign trusts must be reformed to enable New Zealand to comply with its obligations to its treaty partners.

If, contrary to the view expressed in the report (p.18), the implementation of the report's recommendations leads to the demise of the New Zealand foreign trust industry, the real losers will be victims of kidnapping, theft and blackmail who live in countries where privacy of one's personal affairs cannot be taken for granted. These people will in all probability be driven from $\mathrm{New}$ Zealand and be obliged to resort to one of the dwindling number of jurisdictions that, for the meantime at least, offer secrecy.

\footnotetext{
1 [1841] EWHC Ch J82; Cr \& Ph 240; 4 Beav 115; 41 ER 482

2 Land Transfer Act 1952 s. 128, subject to very limited exceptions.

3 Trustees must often wait until the end-of-year accounts are made up to know how much income they can distribute. The Income Tax Act allows six months after the end of the year to pay or apply income that will be treated as derived by the beneficiary in the year when the trustee derived it. This essentially machinery provision has no impact on the matters of principle discussed in this article.

4 Income Tax Act $2007 \mathrm{~s} \mathrm{HC} 26$.

5 Income Tax Act 2007 s HC 29 .

6 This is not to say that the trustee is a 'custodian trustee', who simply looks after property at the behest of an ordinary trustee, though the result would not change if the trustee were a custodian trustee.
}

\section{References}

Dominion Post (2016) 'Tax expert John Shewan sheds welcome light on trusts', 30 June, www.stuff.co.nz/dominion-post/comment/ editorials/81608429/tax-expert-john-shewan-sheds-welcome-light-ontrusts

English, B. (2016) 'Review of foreign trust disclosure rules', media statement, 11 April, https://www.beehive.govt.nz/release/reviewforeign-trust-disclosure-rules, last accessed 1 June 2016

English, B. and M. Woodhouse (2016) 'Government to adopt Shewan recommendations', media release and appendix, 13 July,

http://taxpolicy.ird.govt.nz/news/2016-07-13-governments-responseshewan-inquiry-recommendations\#summary, last accessed 13 July 2016

International Consortium of Investigative Journalists (2016) 'Giant leak of offshore financial records exposes global array of crime and corruption', 3 April, https://panamapapers.icij.org/20160403panama-papers-global-overview.html, last accessed 1 June 2016
Pullar-Strecker, T. (2016) 'Panama Papers: the failed defence for foreign trusts', stuff.co.nz, 11 April, http://www.stuff.co.nz/business/opinionanalysis/78776917/ foreign-trusts-the-defence-deconstructed, last accessed 1 June 2016

Reuters (2016) 'Panama Papers report alleges NZ prime place for rich to hide money', Business Insider, 8 May, http://www.businessinsider. com/r-panama-papers-report-alleges-nz-prime-place-for-rich-to-hidemoney-2016-5/?r=AU\&IR=T, last accessed 12 July 2016

Shewan, J. (2016) Government Inquiry into Foreign Trust Disclosure Rules, Wellington: New Zealand Government

Volcker, P. (1999) Report on Dormant Accounts of Victims of Nazi Persecution in Swiss Banks, report of the Independent Committee of Eminent Persons, http://www.crt-ii.org/ICEP/ICEP_Report_ToC.pdf, last accessed 20 July 2016 